\title{
KAJIAN STRATEGI IMPLEMENTASI PENDIDIKAN KARAKTER ANAK USIA DINI
}

\author{
Prisilia Sandra Habibu' ${ }^{1}$, Rosita Wondal 2 , Bujuna Alhadad ${ }^{3}$ \\ PG PAUD FKIP Universitas Khairun Ternate PG \\ Jl. Bandara Sultan Babullah Kota Ternae Utara. Kode Pos 53 Ternate 97728 \\ Email: prisiliahabibu99@gmail.com
}

\begin{abstract}
Abstrak: Tujuan utama pendidikan karakter adalah untuk memfasilitasi penguatan dan pengembangan nilai-nilai tertentu sehingga terwujud dalam perilaku anak, baik ketika proses sekolah maupun setelah proses sekolah. Agar pendidikan karakter dapat diimplementasikan dengan baik, perluh adanya strategi yang baik pula guna mengoptimalkan penerapan pendidikan karakter pada siswa. Strategi merupakan bagian dari proses perencanaan dan pelaksanaan pembelajaran. Guru wajib memahami serta dapat menentukan strategi-srategi yang akan digunakan dalam pelaksanaan pembelajaran agar diharapkandapat mengoptimalkan kegiatan pembelajaran. Dalam artikel ini, penulis ingin membahas tentang strategi guru dalam mengimplementasikan pendidikan karakter pada anak usia dini. Metode yang digunakan penulis adalah metode kualitatif dengan pendekatan deskriptif. Tujuan penulis adalah untuk membantu guru menentukan strategi khususnya strategi dalam pengembangan karakter anak.Dalam menentukan strategi, sebaiknya ditinjau dari budayadisekitar anak sehingga mudah bagi anak untuk dapat mengaplikasikannya.Terdapat tujuh strategi dalam mengimplementasikan pendidikan karakter yang perluh diketahui guru yakni: 1) tujuan, sasaran dan target yang dicapai harus jelas dan kongkrit, 2) kerjasama antara sekolah dengan orang tua peserta didik, 3) kesadaran dan tanggung jawab guru demi mencapai keberhasilan dari tujuan pendidikan, 4) kesadaran guru dalam mengembangkan karakter peserta didik, 5) memiliki kompetensi pedagogik, 6) dapat memanfaatkan kultur sekolah sebagai pengembangan karakter anak, 7) peran orang tua dalam memonitor dan mengontrol perilaku anak.

Kata Kunci: Strategi, Pendidikan Karakter

Kata kunci:Strategi Pedidikan Karakter
\end{abstract}

Abstract

The main purpose of character education is to facilitate the reinforcement and development of certain values so that they manifest in the behavior of children, either during the school process and after the school process. So that character education can be implemented well, it is also necessary to have a good strategy to optimize the application of character education to students. Strategy is part of the learning planning and implementation process. The teacher must understand and be able to determine which strategies that will be used in the implementation of learning so that it is expected to optimize learning activities. In this article, the author wants to discuss the teacher's strategy in implementing character education in early childhood. The method used by the writer is a qualitative method with a descriptive approach. The aim of the writer is to help the teacher determine the strategy especially the strategy in developing the character of the child. In determining the strategy, it should be viewed from the culture around the child so that it is easy for children to be able to apply it. There are seven strategies in implementing character education that teachers need to know, namely: 1) the goals, objectives and targets achieved must be clear and concrete, 2) collaboration between the school and the students' parents, 3) teacher's awareness and responsibility to achieve the success of the goals education, 4) teacher awareness in developing students' character, 5) 
having pedagogical competence, 6) can utilize school culture as a child's character development, 7) the role of parents in monitoring and controlling children's behavior.

Keywords: Stratgy, Character Education

\section{A. Pendahuluan}

Masa depan anak ditentukan sejauh mana ia mendapatkan pendidikan yang layak sejak dini. Itulah sebabnya muncul anega ragam pendidikan anak usia dini (PAUD) dengan tujuan untuk mencetak generasi yang tidak hanya memiliki pengetahuan, tetapi juga memiliki kepribadian yang baik. Pendidikananak usia dini (PAUD) adalah jenjang pendidikan sebelum jenjang pendidikan dasar yang merupakan suatu upaya pembinaan yang ditujukan bagi anak sejak lahir sampai dengan usia enam tahun ( 6 tahun) yag dilakukan melalui pemberian rangsangan pendidikan untuk membantu pertumbuhan dan perkembangan jasmani dan rohani agar anak memiliki kesiapan dalam memasuki pendidikan lebih lanjut yang diselenggarakan pada jalur formal, nonformal dan informal. Rentang anakusia dini menurut Pasal 28 Undang-Undang Sisdiknas Nomor.20/2003 Ayat 1 adalah 0-6 tahun. Sementara menurut kajian rumpun keilmuan PAUD dan penyelenggaraannya di beberapa negara, PAUD dilaksanakan sejak usia 0-8 tahun (masa emas). Ruang lingkup pendidikan anak usia dini diantaranya: bayi (0-1 tahun) balita (2-3 tahun) kelompok bermain (3-6 tahun), dan sekolah dasar kelas awal (6-8 tahu). Undang-Undang Nomor. 20 Tahun 2003 tentang Sistem Pendidikan Nasional Pada pasal 3 yang menyebutkan bahwa pendidikan nasional berfungsi untuk mengembangkan kemampuan dan serta membentuk karakter peradaban bangsa yang bermartabat dalam rangka mencerdaskan kehidupan bangsa.Adapun pendidikan nasional bertujuan untuk berkembangnya potensi peserta didik agar menjadi manusia yang beriman dan bertakwa kepada Tuhan Yang Maha Esa, berakhlak mulia, sehat, berilmu, cakap, kreatif, madiri dan menjadi warga negara yang demokratis serta bertanggungjawab.Pendidikan anak usia dini atau (PAUD) sangat penting dilaksanakan sebagai dasar bagi pembentukan kepribadian manusia secara utuh, yaitu: Untuk pembentukan karakter budi pekerti luhur, cerdas, ceria terampil dan bertakwa kepada Tuhan Yang Maha Esa. Berdasarkan undang-undang diatas maka pendidikan karakter sangatlah penting untuk membangun peradaban bangsa. Pendidikan karakter tersebut seharusnya sudah ditanamkan sejak anak usia dini sebagai awal pembentukan karakter karena anak berada pada masa usia emas (golden age). karakter sebagai sesuatu yang melekat pada personal yaitu totalitas ide, aspirasi, sikap yang terdapat pada individu dan telah mengkristal didalam pikiran dan tindakan (Tan Giok Lie, 2007). Kecerdasan ditambah karakter, itulah tujuan yang benar dari pendidikan (Abdul Majid, 2011). Pendidikan karakter memiliki tujuan yag sangat penting untuk menopang pembangunan karakter bangsa Indonesia pada umumnya dan keberhasilan pendidikan pada khususnya Marzuki, 2015).

Pembangunan karakter bangsa yang menjadi salah satu perhatian kuat pemerintah sebaiknya disambut baik dan dirumuskan langkah-langkah sistematis dan komprehensif untuk implementasinya dalam proses pendidikan. Tujuan utama pendidikan karakter adalah untuk memfasilitasi penguatan dan pengembangan nilainilai tertentu sehingga terwujud dalam perilaku anak, baik ketika proses sekolah maupun setelah proses sekolah. Terdapat 18 nilai karakter yang harus diketahui diantaranya: Nilai religius, jujur, toleransi, disiplin, kerja keras, kreatif, mandiri, demokratis, rasa ingin tahu, semangat kebangsaan, cinta tanah air, menghargai prestasi, bersahabat/komunikatif, cinta damai, gemar membaca, peduli lingkungan, peduli sosial, tanggung jawab. Untuk dapat melaksanakan kedelapan belas nilai-nilai karakter diatas, maka yang harus diperhatikan adalah (1) perlu tersedianya kurikulum 
berbasis pendidikan holistik, yaitu mengintegrasikan pendidikan karakter kedalam setiap aspek kehidupan sekolah, (2) peran lembaga pendidikan atau sekolah, (3) menciptakan lingkungan yang nyaman dan menyenangkan, (4) meningkatkan guru yang kompeten dan berkarakter. Kecerdasan ditambah karakter, itulah tujuan pendidikan yang sebenarnya. Kecerdasan yang dimaksud disini adalah kecerdasan secara kognitif. Menurut Suyanto (2009) ada 9 pilar karakter yang berasal dari nilainilai luhur universal yaitu: 1) karakter cinta Tuhan dan segenap ciptaan-Nya, 2) kemandirian dan tanggung jawab, 3) kejujuran/amanah, deplomatis, 4) hormat dan santun, 5) dermawan, suka tolong-menolong dan gotong royong, 6) percaya diri dan pekerja keras, 7) kepemimpinan dan keadilan, 8) baik dan rendah hati, 9) toleransi, kedamaian dan kesatuan. Anak-anak memiliki karakter sendiri-sendiri yang berbeda antara yang satu dengan yang lainnya. Karena itu, guru harus mampu memahami aneka karakter yang beragam itu. Untuk memahami karakter anak, pertama-tama guru harus mengetahui bahwa karakter tidak dibentuk oleh dirinya sebagai tenaga pengajar atau pendidik. Guru hanyalah pendamping yang memfasilitasi siswasiswanya. Sedangkan karakter anak, sebagaimana dikemukakan oleh Maria Montessori dalam Absorbent Mind (2008), dibentuk oleh serangkaian aktivitas yang panjang dan lambat yang dijalani oleh anak itu sendiri antara usia tiga tahun hingga enam tahun. Seorang guru adalah memahami sedalam mungkin masing-masing karakter anak didiknya. ketika syarat ini dipenuhi, maka pembelajaran akan berjalan secara efektif dan guru akan disenangi atau disukai oleh anak-anak. Dengan demikian, keberadaan guru dalam membimbing anak-anak usia dini sebenarnya lebih berat dibanding dengan membimbing anak-anak dewasa.

Menurut Thomas Lickona (1991:220), karakter merupakan sifat alami seseorang dalam merespon situasi secara bermoral. Sifat alami itu dimanifestasikan dalam tindakan nyata melalui tingkah laku yang baik, jujur, bertanggung jawab, menghormati dan menghargai orang lain, dan karakter-krakter mulia lainnya.Pendidikan karakter merupakan pendidikan budi pekerti plus, yaitu yang melibatkan aspek pengetahuan (cognitive), perasaan (feeling), dan tindakan (action), tanpa ketiga aspek ini, maka pendidikan karakter tidak akan efektif dan pelaksanaannya pun harus dilakukan secara sistematis dan berkelanjutan serta mampu membedakan satu dengan lainnya. Dengan adanya pendidikan karakter, diharapkan seorang anak akan menjadi cerdas emosinya. berdasarkan fakta dilapangan, guru yang cenderung mengajar tanpa menentukan strategi, proses pembelajarannya tidak akan berlangsung secara optimal. mulai dari durasi waktu membuka serta menutup kelas, bagaimana mengelola kelas, menyampaikan isi pembelajaran pada saat itu serta bagaimana variasi mengajarnya. Thoyibah (2017) melakukan penelitian dan menyimpulkan bahwa pendidikan karakter bukan hanya mengajarkan mana yang benar dan mana yang salah tetapi juga menanamkan kebiasaan tentang yang baik sehingga peserta didik paham, mampu merasakan dan mau melakukannya. Danu Eko Agustinova (2014) juga melakukan penelitian dan bahwa hambatan yang dialami dalam proses penanaman karakter berasal dari dalam dan dari luar. Hambatan dari dalam ditinjau dari pendidik yang kurang bisa memahami karakteristik masing-masing siswa, kurangnya sarana penunjang dalam kegiatan pembelajaran. Sedangkan hambatan dari luar adalah kurang partisipatif orang tua dalam proses penanaman karakter. Penelitian lain dilakukan oleh Juanda (2018) dengan judul penelitian revitalisasi nilai dalam dongeng sebagai wahana dalam pembentukan karakter anak usia dini. Juanda menyimpulkan bahwa, melalui menceritakan dan mendongengkan kita dapat meningkatkan daya imajinasi, emosional, intelektual, rasa sosial, rasa etis, dan religius. Oleh karena itu, orang tua perlu memilihkan jenis dongeng yang benar-benar sesuai dengan perkembangan anak. Berdasarkan pernyataan dan Undang-Undang diatas sehingga 
penulis tertarik untuk membuat suatu kajian kepustakaan guna untuk mengetahui karakter pada anak usia dini.

\section{B. Pembahasan}

Banyak penelitian relevansi yang melakukan penelitian tentang pendidikan karakter. Yang pertama, penulis menemukan penelitian yang dilakukan oleh Muhsinatun (2015) dengan judul penelitian pendidikan karakter anak usia dini melalui main peran (rool playing) di TK Masjid Syuhada, kota baru Yogyakarta, menunjukkan bahwa hasil penelitian yang ditinjau dari media permainan rool playing telah berhasil mempengaruhi pembentukan karakter anak di TK Masjid Syuhada Kota Baru Yogyakarta. Muhsinatun membahas tentang bagaimana mengintegrasikan metode pendidikan karakter dalam metode main peran. Penelitan ini menggunakan penelitian kualitatif dengan pendekatan psikologis dan sosiologis. Teknik pengumpulan data dilakukan dengan pengamatan partisipatif, wawancara dan dokumentasi. Penelitian ini bertujuan untuk mendeskripsikan dan mengetahui hasil pelaksanaan pendidikan karakter anak usia dini melalui main peran (role playing). Penelitian lain dilakukan oleh Eka Sapti Cahyaningrum, dkk dengan judul penelitian pengembangan nilai-nilai karakter anak usia dini melalui pembiasaan dan keteladanan menunjukkan hasil bahwa, penanaman nilai-nilai karakter dilembaga PAUD seKecamatan Ngemplak telah terimplementasikan ditinjau dari penekanan empat karakter dalam proses pembelajaran. Empat karakter tersebut meliputi karakter religius, jujur, toleransi dan disiplin. Penelitian ini menggunakan penelitian tindakan kelas (PTK). Penelitian ini menggunakan siklus tahapan R\&D dari Borg dan Gall. Tujuan dari penelitian ini adalah untuk mengetahui bentuk internalisasi nilai-nilai pendidikan karakter anak usia dini melalui pembiasaan dan keteladanan. Ivonne Hafidlatil Kiromi dan Puji Yanti Fauziah juga melakukan penelitian tentang karakter dengan judul penelitian pengembangan media pembelajaran Big Book untuk pembentukan karakter anak usia dini. Hasil penelitian menunjukkan bahwa media pembelajaran Big Book dapat membantu guru dalam mengembangkan media pembelajaran khsusunya pengembangan untuk pembentukan karakter anak usia dini. Penggunaan Big Book berdampak positif terhadap pembentukan karakter anak. Dengan rata-rata kelas eksperimen lebih tinggi yaitu 43 dan kelas kontrol dengan ratarata 39,14. Ivonne Hafidlatil dan Puji Yanti Fauziah membahas bagaimana prosedur pengembangan media pembelajaran big book yaitu, menentukan nilai karakter yang akan diangkat dalam cerita. Niali karakter terseut adalah kejujuran, disiplin dan menjaga lingkungan, pelaksanaan pengembangan serta menyusun media pembelajaran big book untuk pembentukan karakter anak. Metode penelitian yang digunakan adalah metode reseach and Development. Media pembelajarannya yaitu mengguanakan media pembelajaran Big Book. Data diperoleh melalui teknik wawancara dan lembar penilaian. Subjek penelitian ini yaitu anak kelompok bermain yang berjumlah 28 anak. Tujuan dari penelitian ini adalah untuk membantu guru dalam mengembangkan media pembelajaran khususnya media pembelajarandalam pembentukan karakter anak usia dini di PAUD Bakti Baitussalam Bantul.

\section{Pengertian Karakter}

Menurut kemendiknas (2010), karakter adalah watak, tabiat, akhlak atau kepribadian seseorang yang terbentuk dari hasil internalisasi dari berbagai kebajikan, yang diyakini. Menurut Suyanto (2010), karakter adalah cara berpikir dan berperilaku yang menjadi ciri khas tiap individu untuk hidup dan bekerja sama, baik dalam lingkup keluarga, individu, bangsa dan negara. Adapun individu yang berkarakter baik ini, adalah individu yang bisa membuat keputusan, dan siap 
mempertanggungjawabkan apa yang diperbuatnya, atau berani secara kesatria mempertanggungjawabkan tiap akibat dari aneka keputusan yang dipebuatnya.Yaumi (2016), menyatakan, bahwa karakter adalah moralitas, kebenaran, kebaikan, kekuatan, dan sikap seseorang yang ditunjukkan kepada orang lain melalui tindakan. Rosidatun (2018), karakter dimaknai sebagai cara berpikir dan berperilaku yang khas tiap individu untuk hidup dan bekerja sama, baik dalam lingkup keluarga, masyarakat, bangsa dan negara. Menurut Zulham (2010) ada lima karakter yang harus dikembangkan yaitu 1) trustworthy: meliputi jujur, menepati janji, memiliki loyalitas tinggi, integritas pribadi (komitmen, disiplin, selalu ingin berprestasi), 2) menghormati orang lain: perilaku untuk mementingkan kepentingan umum diatas kepentingan pribadi, siap dengan perbedaan, dan tidak merasa paling benar,3)bertanggungjawab:merupakan gabungan dari perilaku yang dapat dipertanggungjawabkannya, segala hal yang dilakukan harus berani menanggung akibatnya. 4) adil yang meliputi: sikap terbuka, tidak memihak, mau mendengarkan orang lain dan memiliki empati, 5) cinta dan perhatian yang meliputi: menunjukkan perilaku kebaikan, hidup dengan nilai-nilai kebenaran, berbagi kebahagian, bersedia menolong orang lain, tidak egois, tdak kasar dan sensitif terhadap perasaan orang lain.

jadi dapat disimpulkan bahwa, karakter adalah akhlak atau tabiat yang ada dalam diri seseorang yang meliputi: rasa tanggungjawab, peduli, jujur serta sikap hormat dan santun.

\section{Pengertian Pendidikan Karakter}

Pendidikan karakter adalah pendidikan yang menanamkan dan mengembangkan karakter-karakter luhur kepada peserta didik, sehingga mereka memiliki karakter itu, menerapkan dan mempraktekan dalam kehidupannya, entah dalam keluarga, sebagai anggota masyarakat dan warga Negara (Agus Wibowo, 2013).Mulyasah (2012) berpendapat bahwa pendidikan karakter bagi anak usia dini mempunyai makna yang lebih tinggi dari pendidikan moral karena tidak hanya berkaitan dengan benar-salah, tetapi bagaimana menanamkan kebiasaan tentang berbagai perilaku yang baik dalam kehidupan sehingga anak memiliki kesadaran dan komitmen untuk menerapkan kebajikan dalam kehidupan sehari-hari. Pendidikan karakter menurut Ratna Megawangi (2004) adalah usaha untuk mendidik anak-anak agar dapat mengambil keputusan dengan bijak dan mempraktikannya dalam kehidupan sehari-hari. Sehingga mereka dapat memberikan kontribusi yang positif kepada lingkungannya.Pendidikan karakter terhadap anak menurut Edi Waluyo (2007), hendaknya menjadikan mereka terbiasa berperilaku baik, sehingga ketika seorang anak tidak melakukan kebiasaan baik itu yang bersangkutan akan merasa bersalah. Dengan demikian kebiasaan baik sudah menjadi semacam instink yang secara otomatis akan membuat seorang anak merasa kurang nyaman bila tidak melakukan kebiasaan baik itu.Pendidikan karakter sebagai upaya sungguh-sungguh untuk membantu seseorang memahami, peduli dan bertindak

Jadi dapat disimpulkan bahwa pendidikan karakter adalah pendidikan yang tidak hanya mengajarkan tentang baik dan buruk namun juga menanamkan nilai-nilai luhur serta kebiasaan untuk berbuat baik.

3. Nilai-Nilai Karakter

Terdapat 18 (delapan belas) nilai-nilai dalam pendidikan karakter menurut Kementerian Pendidikan Nasional (2013) adalah : 
a. Religius: Sikap dan perilaku yang patuh dalam melaksanakan ajaran agama yang dianutnya, toleran terhadap pelaksanaan ibadah agama lain, dan hidup rukun dengan pemeluk agama lain.

b. Jujur: Perilaku yang didasarkan pada upaya menjadikan dirinya sebagai orang yang selalu dapat dipercaya dalam perkataan, tindakan, dan pekerjaan.

c. Toleransi: Sikap dan tindakan yang menghargai perbedaan agama, suku, etnis, pendapat, sikap, dan tindakan orang lain yang berbeda dari dirinya.

d. Disiplin: Tindakan yang menunjukkan perilaku tertib dan patuh pada berbagai ketentuan dan peraturan

e. Kerja Keras: Tindakan yang menunjukkan perilaku tertib dan patuh pada berbagai ketentuan dan peraturan. Jadi dengan peirlaku tertib ini dapat membangun karakter siswa dalam kehidupan nyata.

f. Kreatif: Berpikir dan melakukan sesuatu untuk menghasilkan cara atau hasil baru dari sesuatu yang telah dimiliki.

g. Mandiri: Sikap dan perilaku yang tidak mudah tergantung pada orang lain dalam menyelesaikan tugas-tugas.

h. Demokratis: Cara berfikir, bersikap, dan bertindak yang menilai sama hak dan kewajiban dirinya dan orang lain.

i. Rasa Ingin Tahu:Sikap dan tindakan yang selalu berupaya untuk mengetahui lebih mendalam dan meluas dari sesuatu yang dipelajarinya, dilihat, dan di dengar.

j. Semangat Kebangsaan: Cara berpikir, bertindak, dan berwawasan yang menempatkan kepentingan bangsa dan negara di atas kepentingan diri dan kelompoknya.

k. Cinta Tanah Air: Cara berpikir, bertindak, dan berwawasan yang menempatkan kepentingan bangsa dan negara di atas kepentingan diri dan kelompoknya.

l. Menghargai Prestasi: Sikap dan tindakan yang mendorong dirinya untuk menghasilkan sesuatu yang berguna bagi masyarakat, dan mengakui, serta menghormati keberhasilan orang lain.

m. Bersahabat/Komunikatif: Sikap dan tindakan yang mendorong dirinya untuk menghasilkan sesuatu yang berguna bagi masyarakat, dan mengakui, serta menghormati keberhasilan orang lain

n. Cinta Damai: Sikap dan tindakan yang mendorong dirinya untuk menghasilkan sesuatu yang berguna bagi masyarakat, dan mengakui, serta menghormati keberhasilan orang lain.

o. Gemar Membaca: Kebiasaan menyediakan waktu untuk membaca berbagai bacaan yang memberikan kebajikan bagi dirinya.

p. Peduli Lingkungan: Sikap dan tindakan yang selalu berupaya mencegah kerusakan pada lingkungan alam di sekitarnya, dan mengembangkan upayaupaya untuk memperbaiki.Hal inis angat penting mengingat bahwa siswa seringkali berinteraksi dengan masyarakat sekitar.

q. Peduli Sosial: Sikap dan tindakan yang selalu ingin memberibantuan pada orang lain dan masyarakat yang membutuhkan.

r. Tanggung Jawab: Sikap dan perilaku seseorang untuk melaksanakan tugas dan kewajibannya, yang seharusnya dia lakukan, terhadap diri sendiri, masyarakat, lingkungan (alam, sosial dan budaya), negara dan Tuhan Yang Maha Esa.

4. Prinsip Pendidikan Karakter

Terdapat 11 prinsip pendidikan karakter yang efektif yaitu:

a. Mempromosikan nilai-nilai kode etik berdasarkan karakter positif 
b. Mendefenisikan karakter secara komprehensif untuk berpikir, berperasaan, dan berperilaku

c. Menggunakan pendekatan yang efektif, komprehensif, intensif, dan proaktif

d. Menciptakan komunitas sekolah yang penuh kepedulian

e. Menyediakan kesempatan kepada siswa untuk melakukan dan mengembangkan tindakan bermoral

f. Menyusun kurikulum yang menantang dan bermakna untuk membantu agar semua siswa dapat mencapai kesuksesan

g. Membangkitkan motivasi intrinsik siswa untuk belajar dan menjadi orang yang baik di lingkungannya

h. Menganjurkan semua guru sebagai komunitas yang profesional dan bermoral dalam proses pembelajaran

i. Merangsang tumbuhnya kepemimpinan yang transfomasional untuk mengembangkan pendidikan karakter sepanjang hayat

j. Melibatkan anggota keluarga dan masyarakat sebagai mitra dalam pendidikan karakter

k. Mengevaluasi karakter warga sekolah untuk memperoleh informasi dan merancang usaha-usah pendidikan karakter selanjunya (Lickona, Schaps \& Lewis).

5. Faktor Pendukung dan Penghambat Pendidikan Karakter

a. Faktor Pendukung Pendidikan Karakter

1) Kepala sekolah, guru dan semua karyawan selalu memberikan keteladanan berupa sikap-sikap yang baik kepada para siswa.

2) Sarana prasarana dan kondisi lingkungan sekolah yang nyaman dan religius.

3) Sikap orang tua yang memperhatikan perkembangan anak. Seperti orang tua yang menjemput anak-anak nya ke sekolah, lalu menanyakan perkembangan anaknya ketika di sekolah kepada guru kelas mereka, dan meminta guru kelas agar melaporkan aktifitas anak yang kurang baik.

4) Program parenting yaitu program yang memberikan kesempatan kepada orang tua untuk selalu terlibat dalam kegiatan-kegiatan yang dilaksanakan oleh pihak sekolah.

5) Kreativitas guru dalam mengembangkan pendidikan karakter.

b. Faktor Penghambat Faktor penghambat meliputi

1) Sikap anak-anak usia prasekolahyang masih labil, dan suka meniru. Karena itu mereka mudah terpengaruh oleh lingkungan sekitarnya terutama dari teman sebayanya.

2) Perbedaan kemampuan dan perkembangan anak.

3) Sikap orang tua yang cenderung menyerahkan pendidikan kepada guru di sekolah.

6. Strategi Penerapan Pendidikan Karakter

Penerapan pendidikan karakter dapat dilakukan dengan berbagai strategi pengintegrasian, strategi yang dapat dilakukan adalah pengintegrasian dalam kehidupan sehari-hari dengan memberikan keteladanan atau contoh, kegiatan spontan, teguran, pegkondisian lingkungan, dan pengintegrasian dalam kegiatan yang diprogramkan dengan membuat perencanaan atas nilai-nilai yang akan diintegrasikan dalam nilainilai yang akan diintegrasikan dalam kegiataan tertentu Masnur Muslich, (2011).Dapat disimpulkan bahwa strategi pendidikan karakter menurut Masnur Muslich merupakan penggabungan antara perencaan dengan program yang telah dibuat berdasarkan nilai-nilai karakter yang kemudian 
dilakukan setiap hari melalui kegiatan secara langsung. Agar pendidikan karakter pada anak berhasil, maka pendidik maupun orang tua harus memilih strategi yang tepat pula, (Agus Wibowo, 2012). Pendidikan karakter diimplementasikan dengan menginternalisasikan nilai-nilai karakter melalui kegiatan pembelajaran, kegiatan ekstrakurikuler, dan kegiatanpembiasaan.Adapun tujuh strategi yang dapat dilakukan dalam implementasi pendidikan karakter melalui kegiatan pembalajaran yaitu (Muhammad Najib dkk, 2016):

a. Sasaran dan target yang akan dicapai harus jelas dan kongkrit

b. Pendidikan karakter akan lebih efektif dan efisien jika dikerjakan tidak hanya untuk sekolah, melainkan harus ada kerjasama antara sekolah dengan orang tua peserta didik.

c. Menyadarkan pada semua guru akan peran penting dan tanggungjawab dalam keberhasilan melaksanakan dan mencapai tujuan pendidikan karakter peserta didik.

d. Kasadaran guru akan perlunya hidden curriculum dan merupakan instrument yang amat penting dalam mengembangkan karakter peserta didik.

e. Dalam melaksanakan pembelajaran, guru harus menekankan pada daya kritis dan kreatif peserta didik, kemampuan kerjasama dan ketrampilan mengambil keputusan.

f. Kultur sekolah harus dimanfaatkan dalam pengembangan karakter peserta didik.

g. Orang tua peserta didik juga memonitor dan mengontrol perilaku sehari-hari peserta didik di lingkungan keluarga dan masyarakat.

Nurzakiyah, (2017), menyatakan bahwa, ada beberap strategi guru yang dapat diterapkan dalam proses pembentukan karakter pada anak diantaranya:

a. Keteladanan atau pemberian contoh kegiatan pemberian contoh atau teladan dapat diberikan oleh orang dewasa disekolah, tidak hanya guru tetapi juga kepala sekolah, kakak kelas, staf sekolah, dan non pendidik.Hal ini sebagai upaya dalam menunjukan kepada peserta didik agar bertindak dan berperilaku minimal seperti yang dicontohkan. Nilai-nilai karaketr yang dapat dicapai dari keteladanan atau pemberian contoh adalah, nilai religius, jujur, tekun, disiplin, peduli.

b. Kegiatan spontan

Kegiatan ini biasanya dilakukan pada saat guru mengetahui sikap/tingkah laku peserta didik yang kurang baik, seperti meminta sesuatu dengan berteriak.

c. Teguran

Guru perlu menegur peserta didik yang berperilaku buruk dan meningkatkannya agar mengamalkan nilai-nilai yang baik sehingga guru dapat membantu mengubah tingkah laku mereka.

d. Pengkondisian lingkungan

Suasana sekolah dikondisikan sedemikian rupa dengan penyediaan sarana fisik. Contohnya, menyediakan alat kebersihan dan tempat sampah untuk mewujudkan nilai gemar membaca, menyediakan slogan-slogan dan aturan untuk mewujudkan nilai kedisiplinan.

e. Kegiatan rutin

Kegiatan rutin merupakan kegiatan yang dilakukan oleh peserta didik secara terus menerus dan konsisten. Contoh kegiatan rutin yang dapat meningkatkan nilai karakter anak adalah mengerjakan dan mengumpulkan tugas tepat waktu. Dalam kegiatan tersebut, terdapat nilai disiplin dan tanggung jawab yang dapat dikembangkan oleh anak sehingga anak terbiasa untuk bersikap disiplin dan tanggung jawab dalam segala hal. 
Upaya untuk mengimplementasikan pendidikan karakter adalah tersedianya kurikulum berbasis Pendekatan Holistik, yaitu mengintegrasikan perkembangan karakter ke dalam setiap aspek kehidupan sekolah. Berikut ini ciriciri pendekatan holistik (Elkind dan Sweet, 2005).

a. Segala sesuatu di sekolah diatur berdasarkan perkembangan hubungan antara siswa, guru, dan masyarakat.

b. Sekolah merupakan masyarakat peserta didik yang peduli di mana ada ikatan yang jelas yang menghubungkan siswa, guru, dan sekolah.

c. Pembelajaran emosional dan sosial setara dengan pembelajaran akademik.

d. Kerjasama dan kolaborasi di antara siswa menjadi hal yang lebih utama dibandingkan persaingan.

e. Nilai-nilai seperti keadilan, rasa hormat, dan kejujuran menjadi bagian pembelajaran sehari-hari baik di dalam maupun di luar kelas.

f. Siswa-siswa diberikan banyak kesempatan untuk mempraktekkan prilaku moralnya melalui kegiatan-kegiatan seperti pembelajaran memberikan pelayanan.

g. Disiplin dan pengelolaan kelas menjadi fokus dalam memecahkan masalah dibandingkan hadiah dan hukuman.

h. Model pembelajaran yang berpusat pada guru harus ditinggalkan dan beralih ke kelas demokrasi di mana guru dan siswa berkumpul untuk membangun kesatuan, norma, dan memecahkan masalah.

Upaya atau strategi lainnya yaitu menciptakan lingkungan yang nyaman dan menyenangkan. Lingkungan yang nyaman dan menyenangkan adalah mutlak diciptakan agar karakter anak dapat dibentuk. Hal ini erat kaitannya dengan pembentukan emosi positif anak, dan selanjutnya dapat mendukung proses pembentukan empati, cinta, dan akhirnya nurani/batin anak.

Meningkatkan guru yang kompeten dan berkarakter adalah strategi lain, namun untuk menjadikan guru yang seperti itu perlu dibekali dengan berbagai pengetahuan dan keterampilan diantaranya:

a. Teori tentang Pentingnya Pendidikan Karakter.

b. Teori dan Implementasi Pendidikan 9 Pilar Karakter secara eksplisit; knowing the good, reasoning the good, feeling the good, and acting the good.

c. Prinsip dan penerapan Brain-based Learning.

d. Penerapan Developmentally Appropriate Practices.

e. Penerapan Multiple Intelligences.

f. Prinsip dan Penerapan Character-based Integrated Learning.

g. Prinsip dan Penerapan Cooperative Learning.

h. Komunikasi Positif dan Efektif.

i. Prinsip dan Penerapan Student Active Learning, Contextual Learning, dan Project-based Learning.

j. Delapan Prinsip Belajar Membaca Menyenangkan.

k. Prinsip dan Penerapan Inquiry-based Learning.

l. Fun Story Telling.

m. Manajemen Kelas.

n. Penerapan sistem Sentra.

o. Character-based Co-Parenting.

p. Training Motivasi.

Dari strategi yang disebut di atas, dapat disimpulkan bahwa setidaknya ada tiga strategi utama dalam pendidikan karakter, di antaranya:

a. membekali siswa dengan alat dan media untuk memiliki pengetahuan, kemauan dan keterampilan 
b. membekali siswa pemahaman tentang berbagai kompetensi tentang nilai dan moral

c. membiasakan siswa untuk selalu melakukan keterampilan-keterampilan berperilaku baik.

Sementara itu, strategi implementasi pendidikan karakter melalui kegiatan pembiasaan dilakukan dengan melakukan upaya berikut ini:1)pembiasaan rutin, 2)pembiasaan spontan, 3)pembiasaan keteladanan, 4)pengkondisian. Jadi dapat disimpulkan bahwa strategi pendidikan karakter bertujuan membantu guru dalam merencanakan kegiatan pembelajaran sehingga pembelajaran nantinya dapat berlangsung secara optimal.

\section{Simpulan}

Setiap guru wajib mengetahui strategi serta mampu memilih strategi yang tepat untuk diterapkan pada kegiatan belajar. Kesimpulan diperoleh dari kajian literatur yang dilakukan oleh penulis terkait strategi guru dalam mengimplementasikan pendidikan karakter diantaranya sebagai berikut:

1. Sasaran dan target yang akan dicapai harus jelas dan kongkrit

2. Pendidikan karakter akan lebih efektif dan efisien jika dikerjakan tidak hanya untuk sekolah, melainkan harus ada kerjasama antara sekolah dengan orang tua peserta didik.

3. Menyadarkan pada semua guru akan peran penting dan tanggungjawab dalam keberhasilan melaksanakan dan mencapai tujuan pendidikan karakter peserta didik.

4. Kasadaran guru akan perlunya hidden curriculum dan merupakan instrument yang amat penting dalam mengembangkan karakter peserta didik.

5. Dalam melaksanakan pembelajaran, guru harus menekankan pada daya kritis dan kreatif peserta didik, kemampuan kerjasama dan ketrampilan mengambil keputusan.

6. Kultur sekolah harus dimanfaatkan dalam pengembangan karakter peserta didik.

7. Orang tua peserta didik juga memonitor dan mengontrol perilaku sehari-hari peserta didik di lingkungan keluarga dan masyarakat.

\section{DAFTAR PUSTAKA}

Abdul Majid, 2011, Pendidikan Karakter Perspektif Islam, Bandung: PT Remaja Rosdakarya.

Agustinova, 2014. Hambatan Pendidikan Karakter Di Sekolah Islam Terpadu, Volume 1, maret 2014.

Cahyaningrum, dkk, 2017. Pengembangan Nilai-Nilai Karakter Anak Usia Dini Melalui Pembiasaan Dan Keteladanan, Volume 6, Edisi 2, Desember 2017

Elkind, David H. dan Sweet, Freddy. 2004. How to Do Character Education. Artikel yang diterbitkanpadabulan September/Oktober.

Juanda, 2018. Revitalisasi Nilai Dalam Dongeng Sebagai Wahana Dalam Pembentukan Karakter Anak Usia Dini, Jurnal Pustaka Budaya. Volume 5, No 2, Juli 2018.

Kemendiknas. 2010. Pengembangan Pendidikan dan Karakter Bangsa. Jakarta.

Kiromi dan Fauziah, 2016. Pengembangan Media Pembelajaran Big Book Untuk Pembentukan Karakter Anak Usia Dini, Jurnal Pendidikan Dan Pemberdayaan Masyarakat. Volume 3-No 1, Maret 2016. 
La Hadisi, 2015. Pendidikan Karakter Pada Anak Usia Dini, Jurnal Al-Ta'dib. Vol.8 No 2. JuliDesember.

Lickona Thomas, 2003. Character Matters: How to Help Our Children Develop Good Judgement, Integrity, and Other Essential, Virtues, New York: Simon \& Schuster.

Lie, Tan Giok, 2007. Pendidikan Dini: Pembentukan Karakter Individu: STT INTI

Marzuki, 2015. Pendidikan Karakter Islam, Jakarta: Amazah.

Megawangi, Ratna. 2004. PendidikanKarakter; Solusi yang TepatuntukMembangunBangsa. Bogor: Indonesia Heritage Foundation.

Montesorri, Maria. 2008. Absorbent MintYogyakarta: Pustaka Belajar.

Muhammad Najib dkk, 2016, Manajemen Strategi Pendidikan Karakter Bagi Anak Usia Dini, Yogyakarta : Gava Media

Muhsinatun, 2015. Pendidikan Karakter Anak Usia Dini Melalui Main Peran (Rool Playing) di TK Masjid Syuhada, Kota Baru Yogyakarta. Tesis UIN Sunan Kalijaga

Mulyasa. 2012. Manajemen PAUD. Bandung: Remaja Rosdakarya

Muslich Mansur. 2011. Pendidikan Karakter: Menjawab Tantangan Krisis Multidimensional. Jakarta: PT Bumi Aksara

Nurzakiyah, 2017. Strategi Pembelajaran Karakter Peserta Didik di SMPN 3 Mapili. Makassar: Universitas Islam Negeri Alauddin

Rosidatun, 2018. Model Implementasi Pendidikan Karakter.Gresik: Caremedia Communication.

Suyanto, Ph.D. 2010. Model Pembinaan Pendidikan Karakter Di Lingkungan Sekolah.Jakarta : Dirjen Dikdasmen Direktorat Pendidikan Dasar Dan Menengah Kementerian Pendidikan Nasional.

Suyanto,2009.UrgensiPendidikanKarakter. Direktorat Jendral Pendidikan Dasar Kementrian Pedidikan Nasional.Diunduh pada April 2012.

Thoyibah, 2017. Implementasi Pendidikan Karakter Anak Usia Dini di TK Pertiwi II Gagaksipat Ngemplak Boyolali. Skripsi. Institut Agama Islam Negeri Surakarta

Undang-Undang No. 20 Tahun 2003 Tentang Sistem Pendidikan Nasional.

Wibowo Agus, 2012.Pendidikan Karakter Usia Dini (Strategi Membangun Karakter Di Usia Emas),

Yogyakarta: Pustaka Pelajar

Wibowo, Agus. 2013. Pendidikan karakter usia dini. Yogyakarta: Pustaka Pelajar

Yaumi, Muhammad, 2016. Pendidikan Karakter Landasan, Pilar \& Implementasi. Jakarta: Prenadamedia Group.

Zulham, Najib. 2010. Pendidikan Berbasis Karakter. Surabaya: Jepe Pres Media Utama 